\title{
Shaping Darkness in hyakki yagyō emaki
}

\author{
Raluca NICOLAE*
}

\begin{abstract}
In Japanese culture, the $y \bar{o} k a i$, the numinous creatures inhabiting the other world and, sometimes, the boundary between our world and the other, are obvious manifestations of the feeling of fear, "translated" into text and image. Among the numerous emaki in which the yokai appear, there is a specific type, called hyakki yagyo (the night parade of one hundred demons), where all sorts and sizes of monsters flock together to enjoy themselves at night, but, in the end, are scattered away by the first beams of light or by the mysterious darani no hi, the fire produced by a powerful magical invocation, used in the Buddhist sect Shingon. The nexus of this emakimono is their great number, hyakki, (one hundred demons being a generic term which encompasses a large variety of yōkai and oni) as well as the night - the very time when darkness becomes flesh and blood and starts marching on the streets.
\end{abstract}

Keywords: $y \bar{o} k a i$, night, parade, painted scrolls, fear

\section{Izvleček}

Yōkai (prikazni, demoni) so v japonski kulturi nadnaravna bitja, ki naseljuje drug svet in včasih tudi mejo med našim in drugim svetom ter so očitno manifestacija občutka strahu "prevedena" v besedila in podobe. Med številnimi slikami na zvitkih (emaki), kjer se prikazni pojavljajo, obstaja poseben tip, ki se imenuje hyakki yagyō (nočna parade stotih demonov), kjer se zberejo pošasti različne vrste in velikosti, da bi uživali v noči, vendar jih na koncu preženejo prvi žarki svetlobe ali skrivnosten darani no hi, ogenj, ki se pojavi z močnim magičnim zaklinjanje in se uporablja pri budistični sekti Shingon. Skupna vez na teh slikah na zvitkih je številčnost hyakki, (sto demonov, generičen termin, ki označuje veliko različnih prikazni in demonov), kot tudi noč - vsakič, ko tema postane meso in kri in začne korakati po ulicah.

Ključne besede: $y \bar{o} k a i$, noč, parada, poslikani zvitki, strah

\footnotetext{
* Raluca NICOLAE, Associate professor, Department of Modern Languages and Business Communication, Bucharest University of Economic Studies.

ralun111[at]yahoo.com
} 


\section{Liminality and the Birth of hyakki yagyo}

Human experience has always set an invisible boundary between familiar and unfamiliar space, between known and unknown. The existence of this liminal space has undoubtedly shaped our sense of reality, and, as a result, people have tried to fill in the blanks and picture the other world by means of their imagination: a realm inhabited by completely different creatures which bear only a slight remembrance of the human world (Komatsu 2003, 7). The average man can only reach the boundary between the two worlds, but a person invested with special powers is able to go beyond it. Consequently, the stories about the other world are actually tales about the liminal space between the two worlds. For instance, demons (oni 鬼) would appear in the mountains or by the gates or bridges because such places have turned out to be portals to the other world. Moreover, the other world does not necessarily points to a certain space, but it also refers to a peculiar time. The roads on which people go back and forth in daylight can easily change into travel routes for supernatural monsters at night (Komatsu 2003, 14-15).

One of the most notable examples in this respect is hyakki yagyo 百鬼夜行 (the night parade of one hundred demons). The notion of hyakki yagyo (alternatively pronounced hyakki yakō) provides a metaphor that transcends historical contexts and serves as a useful point of view through which to interpret many discourses (Foster 2009, 8). The idiom usually indicates a procession of numerous demons and $y \bar{o} k a i^{1}$ who flood the town streets at midnight. The term also refers to the painted scrolls (emakimono 絵巻物) which depict such a nocturnal parade. It was advisable to avoid venturing out on evenings when the hyakki yagyō was known to be on the move. Such times and places represent danger: they were forbidden, unpredictable, beyond the control of human culture (Foster 2009, 9). The Rekirin mondōshū 暦林問答集 (Collection of Discussions of the Forest Almanac), composed by the historian Kamo Arikata (?-1444), advises people against leaving their homes between the hours of 11:00 p.m. and 1:00 a.m. Arikata also identifies the nights when the hyakki yagyo are likely to go out: the nights that follow the days of the first, fifth, sixth, seventh, eighth, and eleventh

\footnotetext{
${ }^{1}$ Yōkai 妖怪 is often translated in English as monster, spirit, goblin, ghost, demon, phantom, specter, fantastic being, lower-order deity, or more amorphously, as any unexplainable experience or numinous occurrence. The term yōkai is more like a contemporary choice; other words are also invoked such as bakemono 化け物 (changing thing), the more childish obake お化け, and the more academic-sounding kaii genshō 怪異現象 (strange phenomena). (cf. Foster 2009, 5)
} 
zodiac signs. Besides washing one's hair or cutting one's nails at the wrong time on the wrong day, venturing out at certain moments of night was a common interdiction among the numerous taboos observed in ancient Japan (Lillehoj 1995, $16)$.

\section{Hyakki yagyō in Literature}

The Ōkagami 大鏡 (The Great Mirror), a fictionalized history from late $11^{\text {th }}$ or early $12^{\text {th }}$ century, refers to an episode in which Fujiwara Morosuke ${ }^{2}$ (908-960) came across a parade of demons while traveling through Kyoto one night in his ox-drawn carriage:

I have not heard what the month was, but he lowered his carriage blinds late one night near the Nijo intersection, while he was traveling south from the Palace along Ōmiya Avenue. "Unyoke the ox and get the shafts down. Get the shafts down", he shouted. The puzzled attendants lowered the shafts, and the escorts and outriders came up to investigate. Morosuke lowered his inner blinds with meticulous care and prostrated himself, baton in hand, as though paying someone every possible mark of respect. "Don't put the carriage on the stand", he said. "You escorts stand to the left and right of the shafts, as close to the yoke as you can, and make your warnings loud. You attendants keep shouting too. Outriders, stay close to the carriage." He began a fervent recitation of the Sonshō Dharanī. The ox had been led out of sight behind the carriage. After about an hour Morosuke raised the blinds. "Hitch up now and go on", he said. His attendants were completely at sea. I suppose he kept quiet about this incident until much later, and then spoke of it only in confidence to close friends, but a queer tale is bound to get out. (McCullough 1980, 136)

The Sonshō Daranī 尊勝陀羅尼 (San. Uş̣n̄işa Vijaya Dhāraṇī) is an incantation praising the protective powers of the deity Butchō Sonshō 仏頂尊勝 (San. Vikìna-uşnisşa), revered as a manifestation of one of the five aspects of the Buddha's wisdom. In Japan and China, the recitation of this dharani was considered effective in warding off evil. The magic of the Sonshō Daran̄ is narrated in a setsuwa 説話 from the Konjaku monogatarishū 今昔物語集 (Collection of Tales of Times Now Past), early $12^{\text {th }}$ century, according to which a young courtier named Mitsuyuki witnessed a procession of demons one night at the Shinsen-en, a large garden in Kyoto. Fortunately, Mitsuyuki's nurse had sewn a copy of the Sonshō Daranī into the collar of his robe, and this saved him from the malevolent power of the nocturnal spirits (Lillehoj 1995, 16-18).

\footnotetext{
${ }^{2}$ Minister of the Right under Emperor Murakami
} 
Coined at the end of Heian and the beginning of Kamakura period, the word hyakki yagyō also appeared in the setsuwa collections Uji Shüi Monogatari 宇治 拾遺物語 (Collection of Tales from Uji), early $13^{\text {th }}$ century, Kohon Setsuwash $\bar{u}$ 古 本說話集 (A Collection of Old Tales) in which demons and monsters emerge one by one in front of the travelers who dare stay overnight in a deserted temple or mansion (Komatsu 2009, 9). In Uji Shüi Monogatari the oni do not come forth in the town or in the deserted temples, but gather in the mountains and partake in a banquet, as in the famous fairytale Kobu-tori oni tachi (The Demons Who Removed the Old Man's Lump) (Ikeda 1971, 503A). In the account from Uji Shīi Monogatari, a monk is travelling alone through the province of Settsu (near the present-day Ōsaka) and he comes upon a deserted temple. He decides to stop there overnight and starts chanting an incantation to the deity Fudō. But all of a sudden, a crowd of one hundred people with torches in hands appears out of thin air, marching into the temple. When they get closer, the monk realizes that they are not actually humans, but very weird creatures, some with only one eye, or some with horns. The monk is terrified and he spends the whole night praying to Fudō to protect him. At sunrise, when the group of oni leaves, he is shocked to discover that actually the place he stopped overnight was not a temple at all. He can hardly find his way back, but, eventually, meets some travellers who inform him that he is in the province of Hizen (an area corresponding roughly to Saga and Nagasaki prefectures), miles away from Settsu (Foster 2015, 16).

According to the above examples, we can identify three types of plots within the hyakki yagyō series: the type of the nocturnal march across the streets of the capital (miyako oji kōshin-gata 都大路行進型), the haunted house type (bake yashiki-gata 化け物屋敷型) and the type of the demonic egression in the mountains (sanchū shutsubotsu-gata 山中出没型) (Komatsu 2009, 13). The otogi $z \bar{o} s h i$ 御伽草子 (companion tales) of the Muromachi period conjured up other hyakki yagyō episodes. In the same period, about 60-70 kinds of emaki and e-hon 絵本 (illustrated books) translated into image this anthropomorphic invasion of yōkai (Tokuda 2009, 29).

\section{Multiplicity and Mutability in hyakki}

The term hyakki 百鬼, literally meaning one hundred demons, does not necessarily encompass a clear-cut number (one hundred), but it refers to a multitude of oni and ill-shaped beings called bakemono (shape shifters), including yōkai (Komatsu 
2010, 8). The traditional image of a Japanese oni is that of a creature with horns, bulging muscles, skin tinted in red, blue or even green, wearing tiger-skin loincloths and carrying an iron club. The oni taking part in the hyakki yagyo in the setsuwa collections are portrayed as: beings with three hands and one foot or with one eye; fierce beast-like creatures with horse/bull/bird/deer heads; demons with two long growing horns from their heads, dancing on one leg; naked creatures of eight $s h a k u^{3}$ high with the skin so black that it seemed coated with lacquer (Komatsu 2009, 9). In the $14^{\text {th }}$ century emaki, Ōeyama e-kotoba 大江山絵詞 (Picture scroll of Mt. Ōe)-Itsuō Museum of Art in Osaka-, the head of the terrifying oni, Shutendōji ${ }^{4}$, is being carried by several warriors.

The enormous head has, obviously, horns, many eyes and a toothy grimace that stretches from ear to ear. While the shape-shifting powers of the oni made it possible for them to take on human form, their gruesome appearance would reflect their evil dispositions, including their penchant for human flesh. (Reider 2003, 133)

Nevertheless, the word hyakki does not only refer to demons, but also applies to yōkai. Oni and yōkai do share certain similarities, but they are different creatures. All oni bring to life the negative human emotions such as envy, jealousy and hate and are able to materialize the strange phenomena that could be neither seen nor described by the human beings. In other words, they give substance to human anxiety. They are supposed to look frightening or aggressive (with horns, claws and fangs) because they are the very embodiments of man's worse fears. Such creatures have crystallized the negative aspects of the shadows and death, while their diversity, typology and the manner in which people perceived them showed meaningful insights into the human history, as well as into the Japanese imagination and creativity (Komatsu 2008, 125-26). Buddhist eschatology never fails to show us the image of hell (rokudō-e 六道絵), inhabited by hordes of

\footnotetext{
${ }^{3}$ Eight feet (about $243.84 \mathrm{~cm}$ )

${ }^{4}$ Shutendōji, the chief of a band of oni, lives on Mt. Ōe, abducting people, particularly maidens, enslaving them and eventually feasting on their flesh and drinking their blood. The concerned Emperor Ichijō orders the warrior hero Minamoto no Raikō and his men to stop the abductions by vanquishing Shutendōji and his followers. When he receives the imperial order, Raikō is a little alarmed because oni are known as powerful transformers who can turn into any being or thing. But the warriors disguise themselves as yamabushi (mountain ascetics) and, with some divine help, they find the oni's Iron Palace where through guile, deception, and with some divine help, they eliminate Shutendōji and his oni band. (cf. Reider 2003, 139-40)
} 
demons who induce even more terror and dread to the sinners ${ }^{5}$. According to Anesaki, the Japanese oni "belongs to a purely Buddhist mythology" (Anesaki et al. 1928, 283). However, oni was also the term used in onmyōdo 陰陽道 (the way of yin and yang) to describe any evil spirits that harm humans. In early Onmyōdō doctrine, the word oni referred specifically to the invisible evil spirits that caused human infirmity (Komatsu 1999, 3). Ancient Japanese literature has assigned a number of different Chinese characters to express the term oni. Among them, the character used now is 鬼, which in Chinese means invisible soul/spirit, both ancestral and evil, of the dead. According to the Wamyo ruijushō 和名類聚抄 (Japanese names_for things_classified and annotated) (ca. 930s), a primitive Japanese encyclopedia, oni is explained as something that is hiding behind things, not wishing to appear. It is a soul/spirit of the dead (Reider 2003, 134-35). Moreover, Yutaka Tsuchihashi assumes that the word oni came from the pronunciation of on 隠 (to hide) plus “i” (Reider 2010, 5).

On the other hand, yokkai were, in the first place, called obake and they referred to tools, objects or animals animated by a spirit. As both oni and yōkai lurked in the darkness, at first glance they were easily mistaken for one another and the painted scrolls depicting the yōkai (yōkai emaki) were commonly known as hyakki yagyo emaki ${ }^{6}$, although, in some cases, no demons appeared in the scrolls (Tokuda 2009, 26-27). From the Kamakura period onward, a prevalent concept was that of

\footnotetext{
${ }^{5}$ The Jigoku zōshi 地獄草紙 (Hell scroll) and Gaki sōshi 餓鬼草紙 (Scrolls of the Hungry Ghosts) produced at the end of the Heian period under the influence of Buddhist thought and the belief in rokudo articulated people's fascination with the unknown and out of ordinary things as unique ways of perceiving fear. To put it simply, these paintings were guided tours of hell. In the $12^{\text {th }}$ and $13^{\text {th }}$ century Japanese stopped fearing hell and rokudo-e. Creatures like the ox-headed gozu 牛頭 or the horse-headed mezu 馬頭, the demons that guarded the entrance to the afterlife, became mere literary characters that gave testimony for the general preference for setsuwa. Across the ages, the numinous fear was sublimated into earthly laughter and the emakimono started to be painted as a means of entertainment (Komatsu et al. 2009, 52). In pre-modern Japan people viewed the unknown world either as terrifying or surprisingly charming (Komatsu 2009, 3), but the plot in hyakki yagyo became redundant in the Edo period. The $y \bar{o} k a i$ were no longer perceived as characters in a contextualized story, but as wondrous "things" that are worth looking at. In the middle of the Edo period, a new field of study became prominent: the hakubutsu-gaku 博物学 (lit.: museum science). This new science started to index and label almost all things in the known world, animals, plants or minerals. Illustrations were attached to the explanations to make the description true to life. A new trend started and there were even requests for paintings or drawings representing bakemono (Kagawa 2009, 45).

${ }^{6}$ Some emaki belonging to Sūfuku-ji in Gifu Prefecture (referred to as the Sūfuku-ji scrolls) are thought to be the earliest surviving examples of the tsukumogami emaki genre (illustrated painted scrolls of transfigured objects), a genre that is similar to the hyakki yagyo emaki but that does not depict the tsukumogami in night parades. (cf. Lillehoj 1995, 21)
} 
tsukumogami 付喪神, animated household objects with arms and legs. According to Tsukumogami-ki, a Muromachi otogi zōshi, when an object reaches one hundred years, it transforms, obtaining a spirit (seirei 精霊) that can deceive people's heart. The word is thought to be a play on tsukumogami, with tsukumo indicating ninetynine and gami (kami) denoting hair; the phrase can refer to an old man's hair as an indication of old age (Foster 2009, 7). Sometimes, the tsukumogami have been placed at the crossroads between humorous and grotesque.

Taking into account the large variety of the characters in the yōkai emakiranging from man-made objects (tsukumogami) to mammals, fish, shell fish and plants - we can pinpoint several major categories of yokkai: animals (as in Chojju jinbutsu giga ${ }^{7}$ or in Tawara no Tōda ${ }^{8}$ emaki, Konkaikōmyō-ji, Kyoto); plants (the tree-like yōkai painted by Kanō Tan'yū in Hōshakukyō zukan', Kyoto National Museum); objects (as in Fudō Riyaku engi emaki ${ }^{10}$, Tokyo National Museum; Tsuchigumo sōshi emaki ${ }^{11}$,Tokyo National Museum; Yūzū Nenbutsu engi emaki ${ }^{12}$, The Art Institute of Chicago, first scroll/Cleveland Museum of Art, second scroll); and oni (Komatsu 2008, 166, 175-76).

The discourse of yōkai is hybrid: it weaves together strands from other discourses - encyclopedic, scientific, literary, ethnographic, folkloric, visual-to create a form of its own (Foster 2009, 3).

Because history and folklore could be passed on in both written and oral form, and because people live in a multi-layered culture, the image might sometimes convey the meaning more accurately than the text ${ }^{13}$ (Komatsu 2009, 2).

\footnotetext{
${ }^{7}$ Belonging to the Kōzan temple in Kyoto, Chōjū-jinbutsu-giga 鳥獣人物戯画 (lit. Animal-person Caricatures; English: Scrolls of Frolicking Animals and Scrolls of Frolicking Animals and Humans) is a famous set of four emakimono drawn at the mid-12 $2^{\text {th }}$ century.

${ }^{8}$ Tawara Tōda 俵藤太 (My Lord Bag of Rice/Rice-bag Tōda) is a fairy tale about a hero who kills the giant centipede Seta to help a Japanese dragon princess and is then taken to the underwater dragon palace to be rewarded with rice bags.

${ }^{9}$ Hōshakukyō zukan 宝積経図巻 (Illustrated Mahāratnakūţa Sūtra).

${ }^{10}$ Fudō Riyaku engi emaki 不動利益縁起絵巻 (Narrative Picture Scroll of About the Priest Shoku's Devotion to his Master Priest in a Serious Illness) (E Museum).

${ }^{11}$ Tsuchigumo sōshi emaki土蜘蛛草紙絵巻. This scroll chronicles the adventures of Minamoto no Raikō, ending in the slaying of the Tsuchigumo, a monstruous spider.

${ }^{12} Y \bar{u} z \bar{u}$ Nenbutsu engi emaki 融通念仏縁起絵巻 (Illustrated Scrolls of the History of Y $\bar{u} z \bar{u}$ Nenbutsu).

${ }^{13}$ When we refer to artistic works such as Chōju jinbutsu giga, we tend to place more emphasis on the visual element than on the narrative, but if we underline the importance of the text, iruibutsu 異
} 


\section{Yōkaika-Creating yōkai}

Along the ages, Japanese artists have tried to picture demons or other creatures dwelling in the Dragon Palace, in hell, or in the upper realm. At the beginning they imagined demons with growing horns, claws and tiger-skin loincloths, but, above all, merciless and dreadful. Secondly, they picked up a certain animal, be it fish or insect, and they altered its realistic depiction by adding human-like features. In the third place, the objects were painted in motion (walking, talking, dancing), as transfigured objects. The specters of the other world were regarded with a considerable amount of fear, therefore, the paintings deliberately boosted the violent aspect of yōkai.

One of the visual means to stimulate fear was to paint the monster as big as possible, especially in contrast with humans (exaggerating its size and dimensions). The menacing figure would loom on helpless, tiny human beings threatening their life with its dark presence. Moreover, the notion of mutability provides an important key to the ontology of the mysterious (Foster 2009, 6). Hybridization is another method employed to wipe out the distinction(s) between species and to cause uncertainty, insecurity and anguish. For instance, by painting two eyes, a nose and a mouth on a tsunodarai 角だらい ${ }^{14}$ whose shape resembles a human head, the artist conjured a yokkai that is both human and object or, to be more specific, that is neither human, nor tsunodarai. Or, by drawing men's heads and putting them in a tree, the humans and the fruit fuse together into the uncanny anatomy of jinmenju 人面樹. This operation is called yōkaika 妖怪化, the transformation into yōkai (Wakasugi 2009, 18-19), by means of which the traditional rules of Arithmetic and Biology are partially or totally abolished: two eyes become one, three or even multiple eyes; the head is placed on the torso or the eyes are relocated on the palm of the hand. Besides hybridization and hyperbolization, yōkaika can be achieved by many other ingenious strategies such as increasing or decreasing the number of the body parts; the standard Mathematics plays tricks on the onlooker by multiplying or reducing the number of body parts. A suggestive example could be Hitotsume kozō 一つ目小僧一 $y \bar{o} k a i$ with the appearance of a child with only one eye in the middle of the forehead, dressed in Buddhist garments. Another effective method is that of

\footnotetext{
類物— types of otogi zōshi depicting strange beings or phantasms - are more relevant in this respect (cf. Komatsu 2008, 234-35).

${ }^{14}$ A two-handled keg for water
} 
wiping off certain body parts: the yōkai Dō no tsura 胴面 underwent such a "operation" only to become a headless creature with the nose, eyes and mouth located on the torso. Yōkaika can also reshuffle certain body parts, placing them in the most unexpected places of abnormality. As the name suggests, the yōkai Tenome 手の目, has his eyes on the palm of his hand in an original attempt to reverse the two perceptions (sight and touch). The artist's skill can create many other yōkai-like shapes by putting grotesque emphasis on certain body parts. The oni in rokudō-e have bulgy muscles or the neck of Rokurokubi 轆轤首 ${ }^{15}$ stretches uncontrollably during sleep. There are some animals, like the cats or the dogs that walk freely on their four paws, but a biped position will push them closer to the human beings. The cat Nekomata 猫又/猫股 is famous for its biped position as well as for its spirit that may haunt humans with visitations from their dead relatives. Needless to say, animals can easily turn into yōkai if they are dressed in human-like clothes and walk on two legs. The same holds true in the case of plants (trees), which fundamentally cannot move, but, by means of yōkaika, are endowed with legs to roam from one place to another (Komatsu 2008, 194-95) (as Tolkien's famous ents-middle-earth plants). Actually, the yōkai in the hyakki yagyō emaki are pictured as having animal-like characteristics (dōbutsuka) or demon-like features (onika) rather than being personified (Komatsu 2008, 1998).

The representations of $y \bar{o} k a i$ have numerous other examples in literature as well as in fine arts. Such works were indexed into three major types: the other world type (ikai emaki taipu 異界絵巻タイプ) such as Urashima Myōjin emaki 浦嶋明神縁起 (The Tale of Urashima) or Amewakahiko zōshi 天稚彦草子 ${ }^{16}$ (The Companion Tale of Amewakahiko); haunted house type ${ }^{17}$ (obake yashiki taipu) such as Tsuchigumo sōshi 土蜘蛛草紙 (Picture Scroll of an Earth Spider) and one hundred demon parade type (hyakki yagyō taipu). Above all, Chōjū jinbutsu giga had, obviously, a major influence on hyakki yagyō emaki since the two emaki caricatured the human life style, the everyday tools, the human garments and speech (Komatsu et al. 2009, 54).

\footnotetext{
${ }^{15}$ A type of female-yōkai whose neck might stretch or even come off and fly around during sleep.

${ }^{16}$ According to Kojiki and Nihon Shoki, Amewakahiko was first sent from the Plain of High Heaven to the residence of the earth kami Ōkuninushi, to pacify the Central Land of Reed Plains and engage in negotiations for its transfer to the Heavenly Grandchild.

${ }^{17}$ The obake yashiki お化け屋敷タイプ (haunted houses) were once places inhabited by humans and then abandoned. After that, they no longer belonged to civilization and the human realm, becoming the dwellings of yōkai and oni.
} 


\section{Procession and the Night (yagyō)}

The procession theme is not singular in the Japanese fine arts and originated in a $12^{\text {th }}$ century illustrated record of the Emperor Go-Shirakawa (1127-1192) travelling from one place to another, but maybe the most famous procession examples are Nenjū gyōji emaki 年中行事絵巻 (Scroll of the Rituals in Daily Life) and Ban Dainagon ekotoba 伴大納言絵詞 (The Tale of Great Minister Ban). The image of the procession was either part of an illustrated story (monogatari-e 物語 絵) or an independent representation of a festival parade. In the $14^{\text {th }}$ century, the image of the procession (gyōretsu-zu 行列図) became a well-known motif in painted scrolls, thus hyakki yagyō emaki followed the general trend of picturing such processions (Wakasugi 2009, 22-23). At the beginning, the procession had aristocratic overtones, but later on, in the Muromachi and the Momoyama periods, common people were able to take part in many festivals and to enjoy the flamboyant parades.

\section{Text and Image — a Fading "Matrimony"}

Gradually, the story behind the image became so shallow that it almost faded away, since the artist's major concern was to depict as many yōkai and oni as possible in a colourful display of shapes, forms, ages and moods. The hyakki yagyō in Spencer Collection at the New York Public Library [Spencer \#112] is one of the rare scrolls that still have written explanations (kotoba-gaki 詞書) accompanying the drawings. The emaki opens with forty-four lines telling of a man besieged one night by a horde of demons in a deserted house east of Sujaku Avenue, south of the Central Gate in Kyoto. The house belonged to a chünagon 中納言 ${ }^{18}$ who had abandoned it when the capital was moved to Fukuhara in the summer of 1180 . Before leaving, the counselor entrusted the house to the care of an old servant.

One day, a visitor arrived at the mansion. Rejoicing in his newfound company, the old caretaker sat the visitor down and began telling him stories. He continued into the early hours of the morning. As the night deepened the old man dozed off, and at the hour of the ox [2:00 a.m.] the visitor began to sense a strange presence at the center of the house. Then, from outside, a weird creature called out in an eerie voice, "Excuse me!" "Who's there?" came the answer, and from the back of the house emerged the frightening sound of footsteps, the likes of which the visitor had never heard before. Terrifying

\footnotetext{
${ }^{18}$ Middle counselor
} 
forms appeared. There were the beings who had been making the strange sounds. The creature who had called out explained, "I was living in the Ömiyadono of Konoe Kawara, but with the recent move of the capital I lost my home. I wanted to find another place to live. That's why I came here." Immediately an unearthly voice answered, saying, "Welcome!" and the creatures all rolled about in delight. One had the appearance of a man, while the others had assumed all sorts of frightening forms. In fact, they were so terrifying that they took the visitor's breath away. Following the first segment of text is a painted scene of the chünagon's estate, with a garden at right and a dilapidated mansion at left. The artist has rendered the structure with tattered bamboo blinds and fukinuki yatai ${ }^{19}$, allowing us to see straight down into the room in which the visitor and the servant sit face to face. This inclusion of human figures and landscape details is another feature that makes the Spencer scroll unusual as a hyakki yakō emaki. The calm of this first scene is shattered in the second scene by two bizarre creatures that rush across the threshold of the chünagon's home. (Lillehoj 1995, 11-13)

Later on, in the $19^{\text {th }}$ century, we encounter another variation the night-procession in an emaki painted by Egawa Buson (1887-?), property of the Boone Collection of the Field Museum of Natural History, Chicago (referred to as the Boone scroll [Boone \#266010]). In this emaki, Buson transplanted the fantastic shapes of the creatures in earlier scrolls and arranged the demons in an original manner. The story is revealed exclusively through images, but the text no longer exists.

The first scene of the Boone scroll shows two demons speaking excitedly, perhaps about events taking place on the other side of a large red gate that seems to mark the edge of a deserted temple compound. Scene two has a pair of demons crouching behind a birch tree staring at a small spirit, which flies through the air toward an ox-drawn carriage at the far left. Dark mists well up around the carriage as it makes a mad dash to escape. Its attendants glance over their shoulders as though sensing the presence of demons approaching from the rear. Scene three reveals that the clumsy, ox-drawn carriage was too slow-the malignant spirits descend upon the carriage en masse. In scene four, a swirling sea of dark mists and smoke part to show demons completing their destructive spree amidst the last remnants of the carriage. Only when the fifth and final segment of the scroll is unrolled do we find ourselves face to face with the person who was riding in the carriage: an elegant gentleman sitting in a meadow surrounded by long, bending blades of grass and pale wild flowers. The gentleman seems quite calm. Eyes closed, he fingers a string of white prayer beads. As dawn breaks and the gloomy mists lift, only one pitiful demon remains. This petite female demon crouches on the ground clutching at her horns, with her long, dark tresses flowing onto the earth in front of her.

19 吹抜屋台, A blown-away roof 
Far to the left, a sliver of the sun peaks out above a bed of clouds. Soft morning light warms the scene and sends the reassuring message that the world is now safe for its human inhabitants. (Lillehoj 1995, 14-16)

\section{Two Polarities in the hyakki yagyō emaki}

Historically speaking, the painted scrolls of hyakki yagyo came forth at the end of the Muromachi and the beginning of the Momoyama era, in a period when old literary productions were revived in form and style to compete with new works (Komatsu et al. 2009, 52-53). The above-mentioned Spencer scroll was particularly important because of the annotations about the uncanny invasion of the supernatural creatures into the human realm, but other hyakki yagyō versions could be found in Kyoto City University of Arts, Hyōgo Prefectural Museum of History, Ōkura Shūkokan Art Museum and Tokyo National Museum etc. Besides these painted scrolls, there are two hyakki yagyo emaki that actually made history in Japanese fine arts: Hyakki yagyō-zu (found in Shinju-an, temple Daitoku, Kyoto), and Hyakki no zu (property of the International Research Center for Japanese Studies, Kyoto). The Shinju-an emaki seems to be one of the oldest hyakki yagyō scrolls, even if it is a copy. The original probably dates back to the Muromachi period (Tokuda 2009, 27-28).

According to a legend about its origin, an itinerant priest decided to spend the night in a deserted temple near Fushimi.

Shocked to hear an unearthly din around midnight, the priest discovered a party of demons and ghosts entering the temple. He fled from the startling sight, shutting himself in an empty room and staying there until daybreak. At dawn he made a hasty departure, heading for the nearest village where he told the villagers of his ordeal. Soon the news reached the artist Mitsunobu, who wanted to paint a convincing likeness of the demons and went straight to the haunted temple. But, though he sat up all night, he saw nothing unusual. In the morning, however, when Mitsunobu opened the shutters, he witnessed an amazing sight: the walls of the temple were covered with an intricate array of ghoulish images. He pulled out his sketchbook and began to copy the weird figures. As he was drawing, Mitsunobu realized that the images were caused by cracks in the damp walls filled with mildew and fungi in a variety of phosphorescent hues. Although enchanting, the tale of Mitsunobu and the haunted temple is probably fictional, invented decades or centuries after the Shinju-an scroll was painted. (Lillehoj 1995, 10)

Almost in the middle of the unfolding Shinju-an emaki there is an intriguing scene that drew the researchers' attention: a huge red demon who releases the other 
$y \overline{o k a i}$ hidden in a crate. The previous interpretations claimed that the demon was threatening the smaller yokai locked in the box, but it is more likely that the demon was actually joining forces with the creatures, trying to take them out to parade on the streets of the town. There is also another important detail in the painted scroll: behind a screen, a few yōkai-ladies were painting their teeth black, a job to be carried out inside the house. This image appears before that of the huge red demon and it clearly reveals spatial indicators, exploring the double folded space of soto and uchi: the familiar place within the house, and the untamed vastness of the outside world. In other words, the crate filled with monsters struggling to break free marks the boundary between two kinds of spaces. Outside the box, the yōkai flock together into the darkness, infesting the streets of the city with terror and grotesque laughter (Tokuda 2009, 27-28). But their whimsical march comes to an end with the first beams of light. A sizzling red globe dominates the last part of the painted scroll, scattering the parading creatures and pushing them back into the darkness they came from. Some researchers interpreted the red ball of light as darani ${ }^{20}$ no hi 陀羅尼の火, the fire produced by the magical invocation performed in the Shingon sect, whereas other scholars saw it as the representation of the rising sun.

On the other hand, the Hyakki no zu, became the property of the International Research Center for Japanese Studies in 2007, therefore it has been a relatively new hyakki yagyo "discovery". Since then, the debates about its accurate age have been going on among the scholars. For instance, Tsuji Nobuo considers that Hyakki no zu was a copy created in the Hōei period (1704-1711), but Hayakawa Monta thinks that it was drawn in the Genroku period (1688--1704). Wakasugi Junji, from Kyoto National Museum, estimated that the painted scroll had originated in the mid- $17^{\text {th }}$ century. This assessment makes it the second oldest version of hyakki yagyo emaki in the history of Japanese fine arts, after the Shinjuan version. Moreover, Wakasugi claims that the original work from which it was copied could be even older than the prototype from which the Shinju-an version was drawn (Komatsu 2008, 55-56).

\footnotetext{
${ }^{20}$ Darani (dharani) were known in Japan as supernatural incantations from the early $8^{\text {th }}$ century. In the exoteric Mahāyāna sutras, dharani are most often represented as mnemonic devices for memorizing scriptural passages and as charms for the protection of those who recite the sutras. They often contain indecipherable phonic fragments, and in Chinese scriptures, they are invariably transliterated (rather than translated) from their original Sanskrit forms. (cf. Kimbrought 2005, 4-5)
} 
The characters marching in Hyakki no zu play an important role in the multilayered imagery of $y \bar{o} k a i$. In contrast with the Shinju-an emaki, in which more than half of the characters are tools and instruments (tsukumogami), the yōkai in the Hyakki no $z u$ are quite diverse and some of them seem to have descended directly from the $12^{\text {th }}$ century painted scroll, Chōju jinbutsu giga. The first to appear "on the stage" is a bird-headed teng $u$ 天狗, holding in hands two burning bones; he is followed by another tengu/oni with an eboshi 烏帽子 ${ }^{21}$ on his head, carrying a halberd on his shoulder; a frog with an eboshi, riding a little dragon-headed turtle, is looking back in surprise at the oni with the halberd; a yōkai with a snail on his head is pulling the dragon-headed turtle by the string; a nyoi 如意 ${ }^{22}$ that has taken on the form of a dragonfly is also looking back at the small group of riders; a little girl (probably a hamaguri ${ }^{23}-y \bar{o} k a i$ ) with a shell on her head is pointing at the nyoidragonfly; her sazae サザエ ${ }^{24}$-headed mother is holding her by her hand; in front of them, a pair of sharp clawed-legs are sticking out from under a white piece of cloth that covers a strange yōkai; a topless and furry yōkai-lady, dressed in a crimson hakama 袴 $^{25}$, is smiling widely, showing her blackened teeth and pointing her finger at the characters behind her; a baku 貘 $^{26}$-looking pet is marching in front of the female-yōkai, tied to a red string held by the strange, furry lady; a yōkai with eboshi, holding in his right hand a loquat leaf and half of a shakubyōshi 第拍 $子^{27}$ and in his left hand the other half, is moving forward, to the left of the emaki; a masked yōkai is trying to put on a wig while looking in a mirror; in the upper part of the emaki, two foxes clad in human garments are talking to each other (one wears a loincloth and an eboshi and the other has a topknot; in spite of his human appearance, the fox's tail that comes out of the white loincloth reveals his true nature); the next in line is a red demon who is trying to threaten the character in front of him; a small dragon with the body covered by a white cloth is looking back at the red oni who is closing in; nearby, a dancing tsunodarai-yōkai is dipping his ladle in a $y \bar{o} k a i$-vessel full of blood; the $y \bar{o} k a i$-vessel is set on a small wheeled vehicle pulled by a wild boar, whipped by a black kettle-yōkai; a cat

\footnotetext{
${ }^{21}$ Originally a headdress worn to indicate a man who had passed his "coming of age" ceremony.

${ }^{22}$ A priest's mace

${ }^{23}$ Clam

${ }^{24}$ Turban shell

${ }^{25}$ Hakama is a traditional Japanese clothing resembling a shirt, but with divided legs, similar to trousers; it is narrower in the waist and looser in the leg.

${ }^{26}$ Looking like a tapir, baku is a $y \overline{o k a i}$ that is said to devour dreams and nightmares.

${ }^{27}$ A musical instrument
} 
skeleton holding a gohei 御幣 ${ }^{28}$ is dancing, following a bony character with another gohei in his hand; a five-storied pagoda dressed in red clothes with susuki 薄 $^{29}$ in his hand is accompanied by another five-storied stone pagoda, with a protruding belly; a tiger clad in priest's clothes is looking to his right, while a wolf dressed in a similar way, holding a folding fan, is looking to his left; a frog wearing an eboshi on his head, stares back half in terror, half in surprise; a red demon, screening his eyes with one hand, glances in the distance at the menacing black clouds; dark fog/smoke, blown by a huge black silhouette, covers the entire sky; the $y \bar{o} k a i$ are terrified by the continuously spreading cloud: a monkey-yōkai is running for his life, with his eboshi slipping off his head; a rabbit dressed in human clothes is looking back in terror and a demon is desperately crawling back, trying to get away of the dark cloud. Black figures are sprouting out of the cloud, marching in a terrifying cavalcade. The wind is blowing hard in a menacing vortex that sweeps off any living creature. The dark stormy procession ends with a $\operatorname{Satan}^{30}$-like image riding a horned animal.

In the painted scroll of Hyakki no zu, the dark cloud at the end spreads over almost one third of the emakimono. All yōkai, bakemono and hyakki are running desperately for their lives as the dark cloud is growing bigger and bigger, like a huge body of a dragon. Is there anything inside the black cloud that is even scarier than the yōkai themselves? Whirlpools are spinning chaotically within the cloud as the lightening is striking here and there in a dreadful symphony. A tornado is almost sucking in all the yokkai that dared stay nearby. At the end of the scroll a black warrior-like shape with a horned helmet is riding a horned animal (Komatsu $2008,51)$. But do the yōkai and oni come forth in the shadows of the night or are they the very source of this gloomy turmoil?

Kondo Yoshihiro asserts that oni were created by people's fear of the destructive power of nature, which manifests as thunder, lightning, storms and earthquakes (Kondo 1966,14). This is probably a result of a combined visual and

\footnotetext{
${ }^{28}$ A staff with plaited paper streamers used in Shinto

${ }^{29}$ Japanese pampas grass

${ }^{30}$ According to Komatsu Kazuhiko, the painted scroll of hyakki yagyō found in Shinju-an and the painted scroll in the International Research Center for Japanese Studies were, at the beginning, distinct emakimono, but they appealed to the artists so much, that they were, at a certain moment, compiled into one painted scroll. This emakimono that unifies the two painted scrolls is nowadays property of Tokyo National Museum (cf. Komatsu 2008, 7). The red globe of light is still there, to scatter the yokai procession, but on the left side, some black horned shapes linger in turbulent obscurity.
} 
auditory intensity of the experience, coupled with the threat of potential, instantaneous destruction. Among the natural forces, lightning is most strongly associated with the oni (Reider 2003, 141).

In Chōju jinbutsu giga, some frogs, rabbits and monkeys are having a party, but in the end all the fun is spoiled by the emergence of a snake that scares and chases away the animals. The whole magic melts away in an instant and the "enchanted" partying frogs return to their usual life. Similarly, the sun or the darani no hi or a dark menacing cloud puts an end to the merry yōkai procession. Even if it is not explicitly expressed in the emakimono, one can easily imagine that afterwards all the yōkai taking part in hyakki yagyo resume their ordinary shape, turning back into animals and household utensils, as if the magic spell had been broken (Reider 2003, 216-17).

Night processions of demons are also found in the early paintings from China. One of the most typical examples includes the commanding figure of Zhong Kui, in Japanese Shoki 鍾馗. In China, as well as in Japan, Zhong Kui has long been revered as the Demon Queller, the vanquisher of evil beings and ghosts, able to command 80,000 demons. He is regarded as a guardian spirit and his image is painted on the gates or on the tiles on the roof of houses. Scholars believe that the original legend of Zhong Kui dates back to the Tang period (618-907). In the $8^{\text {th }}$ century Wu Daozi painted Zhong Kui. Although the original painting disappeared sometime before the Ming period (1368-1644), his dramatic portrayal of the Demon Queller was imitated by generations of Chinese artists who painted a procession of demons marching at night under the command of Zhong Kui (Lillehoj 1995, 19).

The Edo scholar Yamaoka Genrin (1631-1672) explains the oni as follows:

heaven and earth, mountains and rivers, trees and grasses, water and fire, stones and dirt, all sentient beings are yin-yang. The work of yang is called $k a m i$, and the work of $y$ in is named oni. Since all the bad and evil belong to yin, the souls of wicked people are called oni...their [wicked] souls have nowhere to go and nobody worships them. So they linger in the air and cause various problems [to humans]. (Reider 2003, 144)

If we are to take into account Yamaoka Genrin's definition of yin-yang, then we might anticipate two possible closures in hyakki yagyō emaki. The yang type emphasizes light and its apotropaic attributes. In the Shinju-an painted scroll, the light, associated with either the sun or the darani no hi, scatters the yōkai 
procession and restores the human world. On the other hand, the yin type seems to reach its highest point by bringing on a gloomier view and by conjuring black, demonic silhouettes. The yin category could also be called the Shoki-type, because, the parade is dispersed by a more powerful demon who is able subdue the other yōkai. The Hyakki no zu belongs to the latter type. In this respect, both the Shinjuan version and Hyakki no zu seem emblematic because they offer different perspectives on the same phenomenon, the night procession of yōkai on the streets of the capital. The polarities of yin and yang herald either the qualities of light to prevent evil, or the overwhelming demonic force that vanquishes other lesser demons and $y \bar{o} k a i$, and cast them off in a whirl of growing darkness.

\section{Night as the Locus of Creative Plurality}

Night sets the yōkai on the move, but daylight disperses and weakens their evil forces. When the yōkai emerge in the dead of the night, the darkness is so deep that no moon and no stars can be seen up in the sky. However, in addition to the darkness of the night, there is also a different kind of darkness given off by the bodies of yōkai, like a black fog. If these creatures had shown up in the middle of the day, they would have screened the sunlight with a threatening dark cloud (Kagawa 2009, 43-46).

In the painted scrolls of hyakki yagyo, the darkness becomes the nexus of all possibilities, the locus of creative plurality. The dim light favours ambiguity, and ambiguity invites open scenarios. Darkness polarizes all known elements into new forms of gloomy imagination. The branches of a tree could easily pass for the arms of a veracious monster; the roar of a nearby waterfall becomes the wail of a huge phantasm that drives away the belated travelers. Within this quixotic process of recreating reality, the imagination fills in the blanks whenever the eye fails. The glance picks up a couple of familiar elements, and the mind turns them into recreated $y \bar{o} k a i$-like certainties, invested with multiplicity and substance, even with personality and feelings. Mutability and emotional distress forge the very essence of hyakki yagyō. The night parade enables us to apprehend the plurality of darkness as if staring in the distance at numberless, hazy forms that might be there or that were never there.

\section{References}

Anesaki, Masaharu et al. 1928. The Mythology of All Races, vol. 8. Boston: Archaeological Institute of America. 
Emakimono Data Base. Accessed April 2, 2015. http://kikyo.nichibun.ac.jp/emakimono/ detail.php.

E-Museum. Accessed April 2, 2015. http://www.emuseum.jp/detail/100284/000/000?mode $=$ detail \&d_lang $=$ en $\&$ s_lang $=$ en $\&$ class $=\&$ title $=\& c \_e=\&$ region $=\&$ era $=\&$ century $=$ $\&$ cptype $=\&$ owner $=\&$ pos $=145 \&$ num $=1$.

Foster, Michael Dylan. 2009. Pandemonium and Parade. Berkeley: University of California Press.

—. 2015. The Book of Yōkai. Oakland: University of California Press.

Ikeda, Hiroko. 1971. The Type-Motif Index of Japanese Folk Literature. No. 209. Helsinki: Folklore Fellow Communications.

Kagawa, Masanobu. 2009. “Nichibunken-bon no 'Hyakki yagyō no zu' no hakken 日文研 本の「百鬼夜行の図」の発見（Discovering the 'Illustrated Night Parade of One Hundred Demons' in the International Center for Japanese Studies).” Ningen Bunka (Human Culture) 10: 43-46.

Kimbrough, Keller, 2005. "Reading the Miraculous Powers of Japanese Poetry. Spells, Truth Acts, and a Medieval Buddhist Poetics of the Supernatural.” Japanese Journal of Religious Studies 32(1): 1-33.

Komatsu, Kazuhiko. 1999. Oni ga tsukutta kuni-Nihon 鬼がつくった国・日本 (Japan, A Country Created by Oni). Tokyo: Kobunsha.

—. 2003. Ikai to nihonjin 異界と日本人 (The Other World and the Japanese). Tokyo: Kadokawa Shoten.

—. 2008. Hyakki yagyō emaki no nazo 百鬼夜行絵巻の謎 (The Puzzle of the Painted Scroll of the Night Parade of One Hundred Demons). Tokyo: Shūeisha.

—. 2009. “Hyakki yagyō emaki tanjō no nazo o toku 百鬼夜行絵巻誕生の謎を解く (Solving the Puzzle of the Creation of the Painted Scroll of the Night Parade of One Hundred Demons).” Ningen Bunka 人間文化 (Human Culture) 10:4-17.

一, ed. 2010. Yōkai emaki - Nihon no ikai o nozoku 妖怪絵巻・日本の異界を柕く (The Yōkai Painted Scrolls - A Glimpse of the Japanese Other World). Tokyo: Bonjinsha.

Komatsu, Kazuhiko et al. 2009. “Hyakki yagyō no sekai 百鬼夜行の世界 - panel discussion (The World of the Night Parade of One Hundred Demons: panel discussion)." Ningen Bunka 人間文化 (Human Culture) 10: 50-62.

Kondo, Yoshihiro. 1966. Nihon no oni: Nihon bunka tankyū no shikaku 日本の鬼 日本文 化探求の視角 (Japanese Oni Perspectives on the Search for Japanese Culture). Tokyo: Ofusha.

Lillehoj, Elizabeth. 1995. "Transfiguration: Man-Made Objects as Demons in Japanese Scroll.” Asian Folklore Studies 54 (1): 7-34.

McCullough, Hellen Craig, trans. 1980. Ōkagami, the Great Mirror: Fujiwara Michinaga (966-1027) and His Times. Princeton: Princeton University Press. 
Reider, Noriko. 2003. "Transformation of the Oni, From the Frightening and Diabolical to the Cute and Sexy." Asian Folklore Studies 62(1):133-57.

_ 2010. Japanese Demon Lore: Oni, from Ancient Times to the Present. Utah: Utah State University Press.

Tokuda, Kazuo. 2009. “Yōkai no kōshin 妖怪の行進 (The Procession of Yōkai).” Ningen Bunka 人間文化 (Human Culture) 10: 24-31

Wakasugi, Junji. 2009. "Bijutsu-shi no tachiba kara 'igyō irui' to 'gyōretsu' o kīwādo ni 美術史の立場からー「異形異類」と「行列」をキーワードに (The Keywords of 'Grotesque/Monstrous' and 'The Parade': A History of Art Approach).' Ningen Bunka 人間文化 (Human Culture) 10: 18-23. 